\title{
Electrognathographic evaluations of rehabilitated edentulous patients
}

\author{
Avaliações eletrognatográficas em pacientes \\ edêntulos reabilitados
}

\begin{abstract}
Henrique Casselli (a)
Alexandre Brait Landulpho(b)

Wilkens Aurélio Buarque e Silva(c)

Frederico Andrade e Silva ${ }^{(c)}$

(a) PhD Student; (b)Assistant Professor;

(c) Professors - Department of Prosthodontics and Periodontics, School of Dentistry of

Piracicaba, State University of Campinas.
\end{abstract}

\begin{abstract}
This study investigated, through computerized electrognathographic evaluations (K6-I Diagnostic System, Myotronics-Noromed Inc., Tukwila, USA), the mandibular movement pattern of 16 patients rehabilitated with complete dentures presenting no symptoms of stomatognathic functional alterations. The patients were instructed to wear an intra-oral appliance for occlusal plane coverage over their usual superior denture and were then rehabilitated with new dentures preserving a free-way space of $3 \mathrm{~mm}$. After sixty days, the occlusal vertical dimension was increased and the modified inferior dentures were used for another 60 days. The obtained results were submitted to the Tukey Test and to the Friedman test, depending on which variable was under consideration, both at a significance level of $5 \%$. The data revealed a significant decrease in free-way space when the first and the last evaluations were compared. No significant differences were found during opening and closing. It was concluded that the presence of a free-way space at the end of the treatment confirms the importance of its existence for maintaining the balance of the masticatory system, assuming the occurrence of a postural repositioning.
\end{abstract}

Descriptors: Denture, complete; Masticatory muscles; Vertical dimension.

Resumo: O objetivo deste estudo foi avaliar por meio de eletrognatografia computadorizada (K6-I Diagnostic System, Myotronics-Noromed Inc., Tukwila, EUA) o padrão dos movimentos mandibulares de 16 pacientes reabilitados com dentaduras completas, livres de alterações funcionais do sistema estomatognático. Os pacientes foram instruídos a utilizar um aparelho intra-oral de cobertura oclusal plana adaptado na prótese usual superior e então reabilitados com novas próteses preservando a existência de um espaço funcional livre de $3 \mathrm{~mm}$. Após 60 dias promoveu-se um aumento da dimensão vertical de oclusão e as próteses inferiores assim modificadas foram utilizadas por mais 60 dias. Os resultados foram submetidos ao Teste de Tukey e ao Teste de Friedman, dependendo da variável em estudo, ambos com $5 \%$ de significância. Constatou-se decréscimo significante do espaço funcional livre quando compararam-se a primeira e a última avaliações. Não foram encontradas diferenças durante abertura e fechamento. Concluiu-se que a presença de um espaço funcional livre ao final do tratamento vem comprovar a importância de sua existência na manutenção do equilíbrio do sistema mastigatório, admitindo-se que ocorre o reposicionamento postural.

Descritores: Prótese total; Músculos mastigatórios; Dimensão vertical.
Corresponding author:

Henrique Casselli

Av. 41,290 B

Cidade Jardim

Rio Claro - SP - Brazil

CEP: $13501-190$

E-mail: hcasselli@yahoo.com
Received for publication on Ocł 26, 2006

Sent for alterations on Apr 03, 2007

Accepted for publication on May 04, 2007 


\section{Introduction}

There is a consensus that the determining factors in the functional unbalance of the stomatognathic system are those that alter the relationship between teeth, masticatory muscles and the temporomandibular articulations. With this in mind, determination of a therapeutic position before oral rehabilitation is of fundamental importance. ${ }^{3,11}$

Technological development has led to the optimization and application of computerized diagnostic systems such as electrognathography. It is used to corroborate the neuropsychological analysis of the factors linked to prosthetic rehabilitation procedures. ${ }^{9}$ Among these factors, it is important to point-out the maxillomandibular relationship and the occlusal vertical dimension, considering both vertical and horizontal mandibular movements. ${ }^{1,5,8}$ We have therefore considered pertinent to perform a study, with patients rehabilitated with total superior and inferior dentures, directed to monitor the pattern of vertical, sagittal and horizontal movements of the mandible during four pre-established periods through computerized electrognathography.

\section{Materials and Methods}

Sixteen completely edentulous patients were selected for this study, including 6 males and $10 \mathrm{fe-}$ males, with an average age of 53 years, all wearers of total dentures for more then 10 years with no signs of functional stomatognathic disorders. ${ }^{13}$ The patients presented themselves for rehabilitation treatment at the School of Dentistry of Piracicaba, State University of Campinas (UNICAMP), and were submitted to the clinical and physical evaluations required for maintaining clinical records at the Functional Stomatognathic Disorders Study Center (Cetase). ${ }^{6}$

This study was revised and approved by the Research Ethics Committee, School of Dentistry of Piracicaba, State University of Campinas (protocol $\mathrm{n}^{\circ}$. 76/2005).

The sample consisted of patients that had clinical indications of alterations of the occlusal vertical dimension, such as a pronounced impression of the nasolabial fold, wear of the occlusal surfaces of the current total denture teeth and deficient lip contour.

After the first evaluations, the patients were in- structed to wear an intra-oral appliance for occlusal plane coverage, waxed over the superior cast of the current dentures previously mounted on an articulator (Gnatus modelo 9600, Gnatus equipamentos Médico-Odontológicos Ltda., Serrana, SP, Brazil) in maximum intercuspation. The appliance was constructed in thermopolymerized acrylic resin (Clássico Ind. e Com. Ltda., São Paulo, SP, Brazil) respecting the configuration of the occlusal plane in the anteroposterior and latero-lateral direction. Patients were instructed to use the appliance during a period of thirty days during which weekly adjustments were to be made. They were also instructed to remove the appliance only during meals. ${ }^{6}$

Together with the use of the appliance, new superior and inferior total dentures were constructed through the conventional technique. A superior wax plane was adjusted until it became parallel to Camper's plane in a lateral view and parallel to the bipupil line in a frontal view. The superior lip tubercle was used as a reference for the maximum height of the anterior occlusal plane. The free-way space was kept at $3 \mathrm{~mm}$ to determine the occlusal vertical dimension. ${ }^{17}$ An intra-oral recording apparatus was made within the inter-arch distance of the final casts mounted on the articulator. ${ }^{11}$ To trace Gysi's gothic arc record ${ }^{4,13}$ the set was taken to the mouth for the patient to perform the bordering and intra-bordering movements of protrusion, retrusion, and right and left laterality. To establish the point of centric occlusion, the metallic platform was marked with a multi-laminated, 2-mm-in-diameter spherical drill, anteriorly to the vertex of the trace and inside the area corresponding to the bordering movements in order to be tangent to the limits of the trace. ${ }^{11}$ The superior and inferior baseplates were fixed to each other intra-orally with a small amount of chemically-activated acrylic resin (Duralay, Reziance Dental MFG Company, Worth, IL, USA) and with the gimlet over the marking, therefore remounting the inferior cast (Figure 1). The selected artificial teeth (Trubyte Biotone, Dentsply Ind. e Com. Ltda., Petrópolis, RJ, Brazil) were mounted observing the establishment of a balanced bilateral occlusion. ${ }^{15}$ The dentures were installed and were then worn for a period of 60 days.

This period was followed by an increase of the 
occlusal vertical dimension, performed by molding the superior denture with hydrocolloid (Jeltrate, Dentsply Ind. e Com. Ltda., Petrópolis, RJ, Brazil) and obtaining a cast in hard plaster (Herostone, Dentsply Ind. e Com. Ltda., Petrópolis, RJ, Brazil). With the aid of a low-speed steel disc, a block with the teeth of the new inferior denture was removed preserving the integrity of the denture base. The remaining inferior base was repositioned in the patient's mouth and was molded with hydrocolloid, so that an inferior cast of this base was obtained in hard plaster. A pink wax rim (Clássico Ind. e Com. Ltda., São Paulo, SP, Brazil) was adapted to this base, adjusting it with a delicate contact against the occlusal plane of the superior denture in an occlusal vertical dimension equal to that present before the removal of the block of teeth. The superior denture cusp impressions on the wax rim were rebased

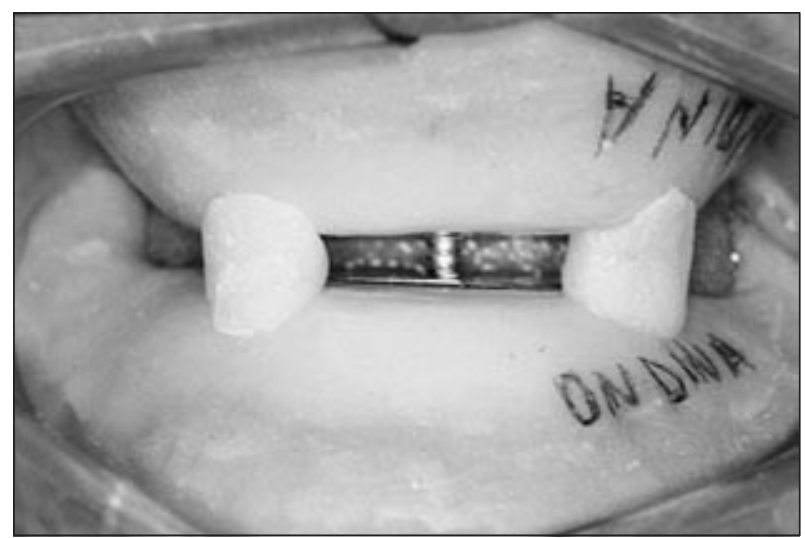

Figure 1 - Baseplates fixed to each other with the set in the centric occlusion point.

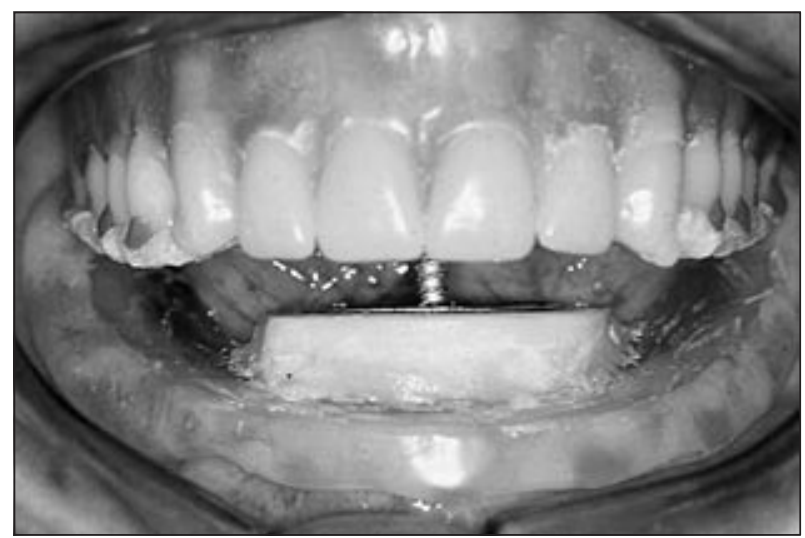

Figure 2 - Record plates repositioned in the mouth with free-way space suppression. with small amounts of zinc oxide-eugenolate paste (Lysanda Produtos Odontológicos Ltda., São Paulo, SP, Brazil) to confirm the relation with greater precision. The facial arc was adjusted and the relation between teeth and wax rim were transferred to the articulator (Gnatus modelo 9600, Gnatus equipamentos Médico-Odontológicos Ltda., São Paulo, SP, Brazil) with the incisal guide pin graduated at " 0 ". Separation of the superior and inferior baseplates from the metallic gimlet/platform set of the intra-oral record apparatus was performed using a carborundum disk, preserving the maxillomandibular relation. The gravitational center of the superior cast was determined and the intra-oral record plates were fixed with chemically-activated acrylic resin (Clássico Ind. e Com. Ltda., São Paulo, SP, Brazil) in the superior cast and in the baseplate of the inferior denture, respecting the following criteria:

1. the gimlet was positioned upon the gravitational center of the superior model;

2. the superior plate was positioned parallel to the superior ramus of the articulator, and

3. the trace vertex was directed to the middle point between the superior central incisors.

The record plates were separated and after verifying that the increase of the vertical dimension was equivalent to the free-way space suppression and that the esthetic requests were satisfied by the adjustments of the gimlet height, the set was transferred from the articulator to the mouth (Figure 2). The patient was requested to repeat the bordering movements obtaining a new centric occlusion point ${ }^{13}$ (Figure 3).

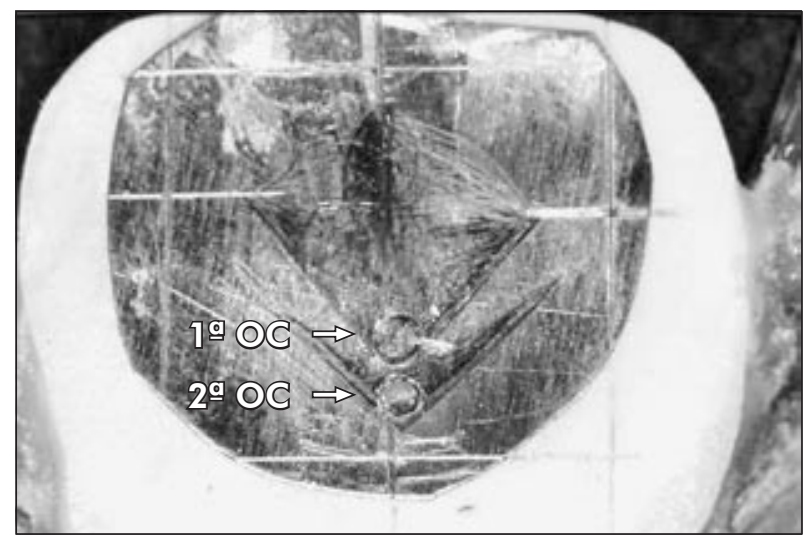

Figure 3 - New centric occlusion point determination. 
The set of intra-oral record plates was fixed with chemically-activated acrylic resin ("Duralay") and was transferred to the articulator with the incisal guide pin graduated at " 0 ". The inferior cast was remounted. The block of inferior teeth was fixed to the base of the inferior denture, interposing bite wax (Clássico Ind. e Com. Ltda., São Paulo, SP, Brazil) between them, and respecting a condition of maximum intercuspation with the antagonist cast. Installation of the denture was accomplished after clinical intra-oral try-in, inclusion, polymerization, finishing and polishing. During a period of approximately 2 days, when the procedures involving occlusal vertical dimension increase were performed, the patients were instructed to use the old dentures with interposition of the occlusal appliance.

Each patient was submitted to a total of four computerized electrognatographic evaluations during the following moments: $1^{\text {st}}$ ) initial (T0), with the usual dentures in position; $2^{\text {nd }}$ ) 30 days (T1) after the installation of the occlusal plane appliance; $3^{\text {rd }}$ ) 60 days (T2) after the installation of the new dentures preserving the free-way space of $\left.3 \mathrm{~mm} ; 4^{\text {th }}\right) 60$ days (T3) after the increase of the occlusal vertical dimension. During evaluations, the patients were placed in a calm environment and seated on a padded chair with both feet totally touching the ground. Arms were put to rest on lateral supports and they were positioned to keep their backs erect and the Frankfort horizontal plane parallel to the floor. A computerized diagnostic system (K6-I, Myotronics, Noromed Inc., Tukwila, WA, USA), which possesses an electrognathograph with eight electromagnetic sensors (K6-I Computerized Mandibular Scanning - CMS), connected to a conventional computer was used to perform the evaluations. While performing the electrognathographic evaluations, the electromagnetic sensors, disposed in a similar structure as that of the facial arc placed on the nasal support, create an electromagnetic field which tracks the movements made by a magnet, glued with its own adhesive (Stomahesive, Convatec-Squibb Co., Princeton, NJ, USA) at the cervical region of the inferior incisors. The protocol to calibrate the eletrognathograph suggested by Jankelson in $1980^{16}$ was followed during all the evaluations. The magnet was to be placed with the patient in maximum habitual intercuspation or, during the second evaluation, in closure upon the occlusal plane appliance, so that its long axis remained parallel to the incisal borders of the superior incisors and so that the magnetic north would be directed to the right side of the patient. Once fixed on the head, the sensors were lined bilaterally parallel to Camper's plane.

\section{Cycle of maximum mouth opening and closing}

Starting at the position of maximum habitual intercuspation, patients were requested to perform a movement of maximum opening followed by closing, and to end again in maximum habitual intercuspation.

\section{Final mandibular closing}

The patients were instructed to remain at rest for a period of approximately seven seconds. After this period the operator requested the patient to perform three subsequent movements of mandibular closing, from rest to maximum intercuspation, covering all the dimension of the free-way space, and finally returning to rest.

For each evaluation, three electromyographic records were made and only the arithmetic average between the values obtained were considered for tabulation of the results. A period of thirty seconds was observed between each record.

\section{Results}

The electrognathographic data for Scan \#1 was submitted to variance analysis, Tukey and Friedman tests with a $5 \%$ significance level; for scan \#3, the Friedman test with a $5 \%$ significance level was applied.

\section{Final mandibular closing}

The free-way space presented significant statistical difference only between the first and last evaluations, admitting inferior values at the end. For the averages of the movements that occurred in the posteroanterior direction, it was possible to observe a significant statistical decrease in the quantity of movement between the first and the second evaluation (Table 1). 


\section{Cycle of maximum mouth opening and closure}

No significant statistical differences were found between the different periods for the four variables studied (Table 2).

\section{Discussion}

When the cycle of maximum opening and closing is observed, the maintaining of a constant vertical dimension opening, considering an occlusal vertical dimension increase of around $8-10 \mathrm{~mm}$ (clinically

Table 1 - Median electrognathographic values, in millimeters, rank averages and statistical analysis of the three variables studied for the different evaluation periods during final mandibular closing.

\begin{tabular}{l|c|c|c}
\hline \multirow{2}{*}{$\begin{array}{c}\text { Evaluation } \\
\text { Periods }\end{array}$} & $\begin{array}{c}\text { Free-Way } \\
\text { Space }\end{array}$ & $\begin{array}{c}\text { Posteroanterior } \\
\text { Movement }\end{array}$ & $\begin{array}{c}\text { Latero-lateral } \\
\text { Movement }\end{array}$ \\
\cline { 2 - 4 } & $2.61(3.43) \mathrm{a}$ & $1.93(3.31) \mathrm{a}$ & $0.38(3.01) \mathrm{a}$ \\
\hline $\begin{array}{l}\text { Initial } \\
\begin{array}{l}30 \text { days after } \\
\text { occlusal } \\
\text { appliance } \\
\text { installation }\end{array}\end{array}$ & $1.35(2.28) \mathrm{ab}$ & $1.08(1.93) \mathrm{b}$ & $0.21(2.12) \mathrm{a}$ \\
\hline $\begin{array}{l}\text { 60 days after } \\
\text { new denture } \\
\text { installation }\end{array}$ & $1.28(2.37) \mathrm{ab}$ & $1.20(2.59) \mathrm{ab}$ & $0.39(2.87) \mathrm{a}$ \\
\hline $\begin{array}{l}\text { 60 days after } \\
\text { occlusal vertical } \\
\text { dimension } \\
\text { increase }\end{array}$ & $1.18(1.90) \mathrm{b}$ & $0.80(2.15) \mathrm{ab}$ & $0.26(1.96) \mathrm{a}$ \\
\hline
\end{tabular}

Note: The median values followed by different letters (lowercase for columns) are different by the Friedman test at the $5 \%$ significance level. measured), reveals the great capacity that muscles have to alter their longitudinal height. Hence, they have the capacity to adapt to a condition of vertical dimension regardless of it being clinically favorable or not. Mastication muscles are able to suffer length and volume alterations when submitted to a stimulus, which also reflect great density alterations. ${ }^{10}$ Even when considering the existing physiological adaptations, it is possible to conclude that the vertical amplitude of mouth opening does not restrict itself to a high or low occlusal vertical dimension. ${ }^{7}$ This dimension seems to be used as a reference to establish the minimum sufficient dimension for food to be captured. However, a decrease of $2.06 \mathrm{~mm}$ in amplitude occurred and this may be related to a mechanism of self-preservation of the muscles. This was observed when the opening dimension present during the last period was close to the limit for neuromuscular spindle activation.

A greater tendency that the mandible had to turn towards the left when performing maximum opening during all periods was observed. The appliances were constructed with the smallest thickness possible to prevent interference with the values of vertical dimension. This unfortunately limited directly its action towards articulations and muscles..$^{12}$ The description made by the studied patients in practicing left unilateral mastication before the beginning of the rehabilitation process and its continuity after the new dentures were installed revealed a higher demand of the lateral pterygoid at the opposite

Table 2 - Average and median electrognathographic values, in millimeters, standard deviations, rank averages and statistical analysis of the variables studied for the different evaluation periods, during the cycle of maximum mouth opening and closing.

\begin{tabular}{l|c|c|c|c}
\hline \multirow{2}{*}{ Evaluation Periods } & \multicolumn{3}{|c}{ Average (standard deviation) } & Median (rank average) \\
\cline { 2 - 5 } & $\begin{array}{c}\text { Maximum vertical } \\
\text { opening }\end{array}$ & $\begin{array}{c}\text { Anteroposterior } \\
\text { Movement }\end{array}$ & $\begin{array}{c}\text { Maximum deviation to } \\
\text { the left }\end{array}$ & $\begin{array}{c}\text { Maximum deviation to } \\
\text { the right }\end{array}$ \\
\hline Initial & $33.47(5.04) \mathrm{a}$ & $18.91(7.63) \mathrm{a}$ & $3.40(1.86) \mathrm{a}$ & $0.40(2.31) \mathrm{a}$ \\
\hline $\begin{array}{l}30 \text { days after occlusal } \\
\text { appliance installation }\end{array}$ & $33.52(4.86) \mathrm{a}$ & $16.71(4.23) \mathrm{a}$ & $3.63(1.55) \mathrm{a}$ & $0.31(2.87) \mathrm{a}$ \\
\hline $\begin{array}{l}60 \text { days after new denture } \\
\text { installation }\end{array}$ & $32.09(4.53) \mathrm{a}$ & $18.28(5.80) \mathrm{a}$ & $2.76(1.69) \mathrm{a}$ & $0.30(2.46) \mathrm{a}$ \\
\hline $\begin{array}{l}60 \text { days after occlusal } \\
\text { vertical dimension increase }\end{array}$ & $31.41(6.18) \mathrm{a}$ & $15.57(5.06) \mathrm{a}$ & $3.54(1.45) \mathrm{a}$ & $0.30(2.34) \mathrm{a}$ \\
\hline
\end{tabular}

Note: The median values followed by different letters (lowercase for columns) are different by the Friedman test at the $5 \%$ significance level for maximum deviation to the right. Averages followed by different letters (lowercase for columns) are different by the Tukey test at the $5 \%$ significance level for all other variables. 
side. This implies an anticipated trigger in relation to the ipsilateral pterygoid when simultaneously demanded. ${ }^{16}$ Another factor that can be related with this tendency is that the appliance did not provide intra-articular space gain, did not favor a better synchronization of the articular structures and, specially, did not favor an adequate repositioning of the articular bands with the disc correctly placed. Although the same intra-oral record was used for maxillomandibular relation measurement for the first and second occlusal vertical dimensions, the system was not appropriately prepared for the great intra-articular space gain that occurred in a sudden manner. ${ }^{12}$ Such evidence suggests that the benefits that the therapy with this appliance provides may also be related to its employment considering the definitive occlusal vertical dimension in which the patient shall be rehabilitated, since the articular mechanic optimization can also offer a better muscular response by the liberation of the disc. ${ }^{2}$

Analysis of the values obtained for the free-way space in the situation of terminal mandibular closing shows a significant decrease of this space during the last evaluation $(1.18 \mathrm{~mm})$ in relation to the first evaluation $(2.61 \mathrm{~mm})$. As previously described, a free-way space of $3 \mathrm{~mm}$ was established for the first occlusal vertical dimension; however, at the end of 60 days using the new dentures, this space presented much smaller values (around $1.28 \mathrm{~mm}$ ). This di-

\section{References}

1. Carr AB, Donegan SJ, Christensen LV, Ziebert GJ. An electrognathographic study of aspects of "deprogramming" of human jaw muscles. J Oral Rehabil. 1991;18(2):143-8.

2. Dawson PE. New definition for relating occlusion to varying conditions of the temporomandibular joint. J Prosthet Dent. 1995;74(6):619-27.

3. Gelb H. Evaluation of static centric relation in the temporomandibular joint dysfunction syndrome. Dent Clin North Am. 1975;19(3):519-30.

4. Gysi A. The problem of the articulation. Part I. Dent Cosmos. 1910;52:1-19.

5. Johnson A, Wildgoose DG, Wood DJ. The determination of freeway space using two different methods. J Oral Rehabil. 2002;29(10):1010-3.

6. Landulpho AB, e Silva WA, e Silva FA, Vitti M. The effect of the occlusal splints on the treatment of temporomandibu- mensional decrease may be related to the detected optimization of the masseter muscles during this phase which, after the improvement of clinical conditions offered by the new dentures, directed the mastication stimulus as an auto-preservation vector, stiffening itself. Because of the $1.26 \mathrm{~mm}$ freeway space difference between the second and first periods and the gain of $1.18 \mathrm{~mm}$ during the fourth period when this space was totally suppressed, it is possible to conclude that the average electromyographic values in the situation of rest did not suffer influence of the thickness with which the occlusal appliance was constructed, nor had any relation with the vertical dimension in which it was adapted, as the same did not interfere in the longitudinal length of the muscles.

\section{Conclusions}

Nature seems to always seek a situation in which the free-way space is preserved and, although not presenting a constant mathematical dimension pattern throughout the interventions performed, the free-way space always tried to establish itself within the most economic and healthy dimension for every established occlusal vertical dimension. This proves once again that the free-way space is not a safe reference to determine occlusal vertical dimension and its maintenance at the end of the treatment highlights the occurrence of a postural repositioning. ${ }^{11,14}$

lar disorders - a computerized electromyographic study of masseter and anterior temporalis muscles. Electromyogr Clin Neurophysiol. 2002;42(3):187-91.

7. McNamara Jr JA, Carlson DS. Functional adaptations in the temporomandibular joint. Dent Clin North Am. 1975;19(3):457-71.

8. Miralles R, Dodds C, Palazzi C, Jaramillo C, Quezada V, Ormeno $\mathrm{G}$ et al. Vertical dimension. Part 1: comparison of clinical freeway space. Cranio. 2001;19(4):230-6.

9. Okeson J. Fundamentos de Oclusão e Desordens Temporomandibulares. $2^{a}$ ed. São Paulo: Artes Médicas; 1992.

10. Raustia AM, Salonen MAM, Pyhtinen J. Evaluation of masticatory muscles of edentulous patients by computed tomography and electromyography. J Oral Rehabil. 1996;23(1):11-6.

11. Silva FA, Silva WAB. Dimensão vertical de oclusão: um método alternativo para sua determinação. RGO. 1991;39(5):377-80. 
12. Silva FA, Silva WAB. Reposicionamento mandibular. Contribuição técnica por meio de férulas oclusais duplas com puas. Rev Assoc Paul Cir Dent. 1990;44(5):283-6.

13. Solberg WK. Background e problemas clínicos. In: Disfunção e desordens temporomandibulares. São Paulo: Santos, 1989. cap. 1, p. 8-13.

14. Tallgren A. The reduction in face height of edentulous and partially edentulous subjects during long term wear. Acta Odontol Scand. 1996;24(2):195-239.
15. Tamaki T. Dentaduras Completas. $3^{\text {a }}$ ed. São Paulo (SP): Sarvier; 1977.

16. Vitti M, Basmajian JV. Integrated actions of masticatory muscles: simultaneous EMG from eight intramuscular electrodes. Anat Rec. 1976;185:173-90.

17. Willis FM. Esthetics of full denture construction. J Am Dent Assoc. 1930;17(4):636-42. 